\title{
A CONCEPÇÃO DE LÍNGUA APRESENTADA NOS PARÂMETROS CURRICULARES NACIONAIS PARA O ENSINO DE LÍNGUA ESTRANGEIRA NO ENSINO FUNDAMENTAL
}

\section{LA CONCEPCIÓN DE LENGUA PRESENTADA EN LOS PARÁMETROS CURRICULARES NACIONALES PARA EL ENSEÑO DE LENGUA EXTRANJERA EN LA ENSEÑANZA FUNDAMENTAL}

\author{
PADILHA, Emanuele Coimbra \\ emanuelecp@hotmail.com \\ UFSM - Universidade Federal de Santa Maria
}

\begin{abstract}
Resumo Este artigo objetiva explicitar a concepção de língua apresentada pelos Parâmetros Curriculares Nacionais (PCNs) de Língua Estrangeira (LE) para o ensino fundamental. O referencial teórico apresenta considerações sobre concepções de língua, um panorama histórico de acontecimentos que marcaram o ensino de línguas estrangeiras no Brasil, desde o surgimento das primeiras escolas, até os PCNs, em 1998. Em seguida, descrevemos os PCNs e discutimos a concepção de língua apresentada por esses documentos. A metodologia utilizada para a identificação da concepção foi a interpretativa com base nos aportes teóricos de Guimarães (2001, 2004, 2009), Koch (2006) e Travaglia (2009). Os resultados demonstram que a concepção que permeia o documento é a de que a linguagem é o lugar da interação humana. Por meio dela, ideias, pensamentos e intenções são expressos e os indivíduos estabelecem relações com outras pessoas.

Palavras-chave: Concepção de língua. Ensino fundamental. Língua estrangeira. Parâmetros Curriculares Nacionais.
\end{abstract}

Resumen Este artículo objetiva explicitar la concepción de lengua presentada por los Parámetros Curriculares Nacionales (PCNs) de Lengua Extranjera (LE) para la enseñanza fundamental. El referencial teórico presenta consideraciones sobre concepciones de lengua, un panorama histórico de acontecimientos que marcaron la enseñanza de lenguas extranjeras en Brasil, desde el surgimiento de las primeras escuelas, hasta los PCNs, el 1998. En seguida, describimos los PCNs y discutimos la concepción de legua presentada. La metodología utilizada para la identificación de la concepción fue la interpretativa con base en los aportes teóricos de Guimarães $(2001,2004,2009)$, Koch (2006) y Travaglia (2009). Los resultados muestran que la concepción que permea el documento es la de que el lenguaje es el lugar de la interacción humana. Por medio de ella, ideas, pensamientos e intenciones son expresos y los individuos establecen relaciones con otras personas.

Palabras clave: Concepción de lengua. Enseñanza fundamental. Lengua extranjera. Parámetros Curriculares Nacionales.

\section{INTRODUÇÃO}

Desde o início da história das civilizações, o interesse pelas línguas estrangeiras esteve presente. Os homens sentem necessidade de aprender outras línguas, devido a variadas finalidades, principalmente para interação com outros indivíduos. Nas palavras de Paiva (2003, p. 01), "as línguas servem de mediadoras para ações políticas e comerciais, além de veicularem o conhecimento científico e a produção cultural". 
No contexto de ensino brasileiro, as questões políticas sempre se relacionaram à inserção das línguas estrangeiras como disciplinas escolares (LEFFA, 1999). Embora atualmente a língua inglesa e a espanhola tenham lugar de destaque entre as línguas estrangeiras ofertadas nas escolas brasileiras, a história nos mostra que nem sempre foi assim. Interesses políticos e econômicos sempre estiveram diretamente relacionados à escolha da língua estrangeira a ser inserida nos currículos escolares (MULIK, 2012). Assim, da maneira como ocorreu o ensino de línguas no Brasil, nem sempre ficou claro se os brasileiros estudam uma determinada língua para atender a interesses do nosso país ou se estudam para servir ao interesse dos outros (LEFFA, 1999).

Nessa perspectiva, do mesmo modo que a escolha de uma língua estrangeira está ligada a aspectos políticos, a elaboração dos documentos oficiais que embasam o ensino escolar também está atrelada a uma concepção de língua do momento histórico no qual é produzido. Considerando esse contexto, esta pesquisa objetiva explicitar a concepção de língua apresentada pelos Parâmetros Curriculares Nacionais (PCNs) de língua estrangeira (LE) para o ensino fundamental (BRASIL, 1998) que, apesar de ter sido elaborado em 1998, ainda é o documento oficial que serve como referência base para o ensino de línguas no contexto atual.

Para atender a essa finalidade, no primeiro momento, apresentamos considerações teóricas sobre concepções de língua; em um segundo momento, um panorama histórico, a partir de acontecimentos políticos e documentos oficiais, que marcaram o ensino de línguas estrangeiras no Brasil, desde o surgimento das primeiras escolas, até o surgimento dos PCNs, em 1998. Na sequência, descrevemos os PCNs e discutimos a concepção de língua apresentada por tal documento; e, para finalizar, tecemos as considerações finais deste trabalho.

\section{CONCEPÇÃO DE LÍNGUA E LINGUAGEM}

Conforme Guimarães (2004, p. 11), “fazer história é uma prática das mais antigas e tomou várias formas no decorrer dos séculos. A produção de uma história 


\section{Atos de Pesquisa em Educação - ISSN 1809-0354 \\ Blumenau, v. 13, n.1, p.152-168, jan./abr. 2018 \\ DOI: http://dx.doi.org/10.7867/1809-0354.2018v13n1p152-168}

das Ideias deve acompanhar a formação de práticas de conhecimento, de conceitos, de noções". Dentro da perspectiva da História das Ideias Linguísticas, consideramos fundamental a relação entre o domínio do saber sobre o qual se quer fazer história e as instituições em que esse saber se constitui. Nesse caso, para este trabalho, referimo-nos à produção de um saber linguístico sobre concepção de língua e estudos da linguagem; e como esse saber se reflete nas instituições escolares por meio dos documentos oficiais que norteiam o ensino no Brasil.

Seguindo Guimarães (2004), ao mencionar Auroux (1985, 1989), é necessário que uma história das ideias considere uma análise de obras específicas ou documentos pertinentes que, em determinada instituição, refletem aspectos específicos da produção do saber. Desse modo, Guimarães (2004) coloca como elementos fundamentais a posição expressa por Auroux $(1989,1992)$ sobre a análise do que chama de horizonte de retrospecção e projeção. Isso quer dizer que, para compreendermos um determinado momento histórico, devemos considerar a constituição de um passado e ao mesmo tempo de um desdobramento futuro desse acontecimento. Nas palavras do autor:

A história das ideias envolve de um lado três tipos de elementos: as instituições, os acontecimentos nas instituições que organizam as práticas de produção de conhecimento, as obras que formulam este conhecimento, ou dito de outro modo, que resultam do conhecimento produzido. (GUIMARÃES, 2004, p.11).

Nesse sentido, as Ideias Linguísticas tratam com a questão da língua, com a produção de um conhecimento sobre ela, com a produção de instrumentos tecnológicos a ela ligados e as relações destes elementos com o povo que a fala (ORLANDI, 2002). É pela trajetória histórica desses instrumentos que encontramos indícios de uma descrição linguística no Brasil.

Desse modo, a circulação do conhecimento linguístico que é produzido pela sociedade contemporânea pode se dar de duas formas: de um lado, pode ocorrer no interior da comunidade científica, na qual locutores e destinatários são especialistas. Por outro lado, o conhecimento pode circular para setores ou para a sociedade como um todo; nesse caso, o destinatário é o público que espera o resultado da ciência, que é a chamada divulgação científica, realizada tradicionalmente pela 


\section{Atos de Pesquisa em Educação - ISSN 1809-0354 \\ Blumenau, v. 13, n.1, p.152-168, jan./abr. 2018 \\ DOI: http://dx.doi.org/10.7867/1809-0354.2018v13n1p152-168}

escola (GUIMARÃES, 2009). Dessa forma, o saber científico se desdobra em relação a esse domínio discursivo, no qual ele se coloca como um saber acadêmico pedagogizado, tornando-se mais didático; é assim que chega ao contexto escolar (SCHERER et. al, 2015).

Para tratarmos da forma como esse conhecimento sobre a língua chega à escola, primeiramente é necessário que localizemos brevemente, dentro da história, quais os principais desdobramentos teóricos sofridos pela Linguística, até chegar ao momento atual, refletindo essas concepções de língua nos documentos oficiais que norteiam o ensino.

O interesse pela linguagem vem desde a antiguidade; e, em cada época, há o surgimento de uma concepção de língua e linguagem que busca substituir a anterior, que se configurava como a teoria mais adequada e atual daquele momento. $\mathrm{O}$ pensamento moderno sobre a linguagem instaura-se com a Linguística Comparativa, no século XIX, na qual a linguística toma por objeto a mudança linguística e o interesse recai sobre a reconstituição do passado linguístico das línguas europeias e asiáticas. O trabalho do linguista aqui são as formas do processo de mudança das línguas e a preocupação principal é a relação genealógica entre as línguas (GUIMARÃES, 2001).

Os estudos sobre a linguagem que temos hoje começaram a aparecer no século $X X$ com Saussure, com a definição da língua como objeto específico da Linguística e a concepção de língua como sistema. A Linguística, desse modo, assume um caráter científico. Essa concepção de língua substitui a concepção naturalista própria do comparatismo. Posteriormente a Saussure, os estudos da linguagem passam por vários desdobramentos e adquirem direções variadas, desde aqueles que os renovaram a partir da concepção de sistema, até os que partindo do que foi definido por Saussure, incluíram no linguístico a noção de sujeito, como Benveniste, por exemplo. Outros caminhos direcionam para o funcionalismo de Jakobson, que considera a linguagem como sistema de comunicação.

Um segundo momento da Linguística do século $X X$, conforme Guimarães (2001), é marcado pelo cognitivismo de Chomsky que a considera, na sua perspectiva biológica da linguagem, como instrumento para a expressão do 


\section{Atos de Pesquisa em Educação - ISSN 1809-0354 \\ Blumenau, v. 13, n.1, p.152-168, jan./abr. 2018 \\ DOI: http://dx.doi.org/10.7867/1809-0354.2018v13n1p152-168}

pensamento. Nesse sentido, a Gramática Gerativa de Chomsky coloca como central na Linguística as relações entre as unidades linguísticas entre si (sintaxe). $O$ conhecimento sobre as línguas é concebido como um conjunto de regras para formar frases. Nessa concepção, a capacidade para falar é inata; as pessoas falam porque têm um órgão da linguagem.

No século XX também encontramos autores, como Labov, que em um movimento oposto ao da universalidade de Chomsky, pensa a língua como uma estrutura variável, que é estabelecida por correlações entre estratificação social e a variedade das estruturas linguísticas.

Seguindo Guimarães (2001, p.5), um terceiro movimento na história dos estudos linguísticos, no século $\mathrm{XX}$, concebe a língua a partir de uma perspectiva teórica que considera "a relação entre exterioridade e o linguístico como uma relação histórica e constitutiva do processo linguístico".

Atualmente, no século XXI, em uma cena contemporânea, para Guimarães, vivemos entre:

a) um cognitivismo naturalista que o pensamento chomskyano reintroduziu e que localiza a linguística no interior da biologia (enquanto ciência psicológica), ou seja, das ciências naturais; b) posições derivadas do estruturalismo, como os estudos enunciativos, para os quais o funcionamento da língua se dá porque a língua está marcada por formas próprias para seu funcionamento no acontecimento enunciativo, posições então que mantêm a questão da autonomia do linguístico posta por Saussure; c) posições que procuram estabelecer diálogos entre as diversas disciplinas das ciências humanas que levam a pensar o linguístico como definido por uma correlação com o que está fora do linguístico: o antropológico, o social, o psicológico, etc. d) posições como a da análise de discurso que põem em cena a questão de que não se pode reduzir 0 linguístico nem ao social (antropológico) nem ao psicológico, pois a linguagem é, ao lado de integralmente linguística - num certo sentido saussureano - também integralmente histórica (GUIMARÃES, 2001, p. 06).

Além dos principais momentos dos estudos da linguagem até os dias atuais, para que consigamos compreender a concepção de língua trazida pelos PCNs (BRASIL, 1998) para o ensino de língua estrangeira no ensino fundamental na atualidade, consideramos como indispensável também apresentar quais foram as principais concepções de língua predominantes na história da Linguística, antes de discutirmos a concepção que predomina no documento analisado. 


\section{Atos de Pesquisa em Educação - ISSN 1809-0354 \\ Blumenau, v. 13, n.1, p.152-168, jan./abr. 2018 \\ DOI: http://dx.doi.org/10.7867/1809-0354.2018v13n1p152-168}

A concepção de língua considerada mais atual e mais recorrente nas pesquisas realizadas em determinada época se reflete na elaboração dos documentos oficiais que norteiam o ensino de cada período histórico. Desse modo, é necessário que retomemos as principais concepções de língua que perpassaram a história das ideias linguísticas e que contribuíram na definição dos conteúdos e dos métodos a serem adotados na escola. Essas concepções de linguagem estão diretamente relacionadas com o ensino-aprendizagem de línguas. A forma como se concebe a linguagem interfere/implica na metodologia adotada pelos professores para a sua prática; "o modo como se concebe a língua altera em muito como se estrutura o trabalho com a língua em termos de ensino" (TRAVAGLIA, 2009). Vários autores brasileiros já discutiram a relação entre a concepção de linguagem e sua importância para ensino. Dentre eles, podemos citar, por exemplo, Koch (2006) e Travaglia (2009).

Dentro da história dos estudos linguísticos, três são as concepções de linguagem que normalmente permeiam o ensino de línguas: a primeira é a linguagem como expressão do pensamento (concepção tradicional da língua); a segunda, a linguagem como instrumento de comunicação (concepção estrutural) da língua; e, a terceira, a linguagem como uma forma ou processo de interação/lugar de interação (concepção interacionista da língua). A seguir, apresentamos os pontos fundamentais de cada uma dessas concepções:

Para a primeira concepção, a linguagem como expressão do pensamento, expressar-se está diretamente relacionando ao pensar. Desse modo, as pessoas que não pensam ou não pensam bem, não se expressam bem. Em outras palavras, pensar é o requisito básico para se expressar e organizar ideias de maneira lógica.

A expressão ocorre no interior da mente das pessoas, e a linguagem traduz a expressão no interior da mente, é o espelho do pensamento (TRAVAGLIA, 2009). A enunciação é um ato individual, que não é afetada pelas circunstâncias que constituem a situação social em que a enunciação/expressão acontece. Ela é decorrente da capacidade de o indivíduo articular de maneira lógica o seu pensamento, por meio de uma linguagem articulada e organizada. A organização do pensamento segue regras para que exista uma organização lógica, e, por 


\section{Atos de Pesquisa em Educação - ISSN 1809-0354 \\ Blumenau, v. 13, n.1, p.152-168, jan./abr. 2018 \\ DOI: http://dx.doi.org/10.7867/1809-0354.2018v13n1p152-168}

conseguinte, ocorra a linguagem. Essa concepção de linguagem está relacionada com os estudos denominados por gramática normativa ou tradicional.

Já na segunda concepção, a linguagem como instrumento de comunicação, "a língua é uma estrutura disponível ao uso dos falantes, mas sobre a qual possuem reduzida atuação" (KOCH, 2006, p.35). Nessa perspectiva, a língua é concebida como um código, "um conjunto de signos que se combinam segundo regras, e que é capaz de transmitir uma mensagem, informações de um emissor a um receptor" (TRAVAGLIA, 2009, p.22). Assim como a primeira concepção, esta também apresenta caráter monológico: o emissor codifica e o receptor decodifica. $O$ código/língua é um ato social, que exige pelos menos dois participantes, os quais necessitam dominar o mesmo código - preestabelecido e convencional - para que a transmissão de informações ocorra. Essa concepção está relacionada aos estudos da Teoria da Comunicação. De acordo com Travaglia (2009, p.22):

\footnotetext{
Essa concepção levou ao estudo da língua enquanto código virtual, isolado de sua utilização na fala (cf. Saussure) ou no desempenho (cf. Chomsky). Isso fez com que a Linguística não considerasse os interlocutores e a situação de uso como determinantes das unidades e regras que constituem a língua, isto é, afastou o indivíduo falante do processo de produção, do que é social e histórico na língua. Essa é uma visão monológica e imanente da língua, que a estuda segundo uma perspectiva formalista que limita esse estudo ao funcionamento interno da língua e que separa o homem no seu contexto social.
}

Por outro lado, já na terceira concepção, a linguagem é uma forma ou processo de interação, a linguagem é o lugar da interação humana, na qual se constituem as relações sociais. Essa é a mais divergente das três concepções, pois, aqui, ao contrário do que ocorre na primeira e na segunda concepção, o indivíduo é um sujeito ativo que age e pratica ações por meio da linguagem e atua sobre 0 interlocutor. Ele não se restringe simplesmente a decodificar e traduzir o código como expressão do pensamento (TRAVAGLIA, 2009). A interação comunicativa produz efeitos de sentidos, em uma determinada situação e num contexto sóciohistórico determinado. A língua é um reflexo das relações sociais.

Essa concepção é representada por todas as correntes de estudo da língua que constituem a linguística da enunciação, na qual estão incluídas teorias como a 


\section{Atos de Pesquisa em Educação - ISSN 1809-0354 \\ Blumenau, v. 13, n.1, p.152-168, jan./abr. 2018 \\ DOI: http://dx.doi.org/10.7867/1809-0354.2018v13n1p152-168}

Linguística Textual, a Teoria do Discurso, a Análise do Discurso, a Análise da Conversação, a Semântica Argumentativa e todos os estudos que estão ligados à Pragmática e às abordagens interacionistas da linguagem.

Depois da apresentação dos principais momentos dos estudos da linguagem e das principais concepções de língua que predominam na história da Linguística, na próxima seção, objetivamos apresentar brevemente os principais acontecimentos históricos, que marcaram/influenciaram o ensino de línguas estrangeiras no Brasil, traçando um panorama do ensino de LE, desde o surgimento das primeiras escolas, até o surgimento dos PCNs, em 1998.

\section{HISTÓRIA DO ENSINO DE LÍNGUA ESTRANGEIRA NO BRASIL}

Historicamente, o ensino de línguas no Brasil é um reflexo do que aconteceu em outros países; no entanto, em nosso país, geralmente as tendências para o ensino, bem como concepções de línguas e metodologias a serem seguidas, sempre sofreram um atraso de alguns decênios (LEFFA, 1999).

Deixando de lado os primórdios da catequização dos índios, e partindo das primeiras escolas fundadas pelos jesuítas, podemos dizer que a tradição brasileira é de uma grande ênfase no ensino de línguas, inicialmente com as línguas clássicas latim e grego -, e posteriormente com as línguas modernas: francês, inglês e italiano. Destacando que a língua espanhola, apesar de apresentar um lugar de destaque atualmente, junto ao inglês, teve sua inclusão nos currículos escolares no ano de 1942, com a Reforma Capanema1.

Durante o período colonial, antes e depois da expulsão dos jesuítas pelo Marquês de Pombal, as línguas ensinadas dominantes eram o grego e o latim. Em 1808, com a chegada da Família Real e, posteriormente em 1837, com a criação do Colégio Pedro II, lentamente os currículos da escola secundária começaram a evoluir e a considerar o ensino de línguas modernas. Os alunos passaram, em média, a estudar no mínimo quatro, cinco ou até mesmo seis línguas (latim, grego,

\footnotetext{
${ }^{1}$ Nome dado às reformas realizadas no sistema educacional brasileiro, durante a Era Vargas, lideradas pelo então Ministro da Educação e Saúde, Gustavo Capanema.
} 
francês, inglês, alemão, italiano), com uma carga horária semanal de duas a três horas (LEFFA, 1999).

Durante a República, principalmente com a reforma de Fernando Lobo, em 1892, ocorreu uma redução significativa da carga horária semanal do ensino de línguas: de 76 horas semanais/anuais em 1982, chegou-se em 1925 a 29 horas. $O$ ensino do grego desaparece, o italiano não é oferecido ou torna-se facultativo, e o inglês e o alemão passam a ser oferecidos de modo exclusivo.

Com a criação do Ministério da Educação e Saúde Pública, em 1930, e com a Reforma de Francisco Campos, em 1931, no que se refere ao ensino de línguas, foram introduzidas mudanças com relação ao conteúdo (ênfase nas línguas modernas e não no aumento da carga horária - diminuição do número de horas do latim) e com relação à metodologia de ensino (Método Direto², já adotado na França, desde 1901).

Em 1942, com a Reforma Capanema, as línguas estrangeiras adquiriram maior importância. Todos os alunos, desde o ginásio até o científico, estudavam latim, francês, inglês e espanhol.

A Lei de Diretrizes e Bases (LDB), de 1961, retirou o latim do currículo; e o francês, quando não totalmente retirado, teve sua carga horária diminuída. Já o inglês se manteve inalterado. A LDB reduziu o ensino de língua a menos de $2 / 3$ do que foi na Reforma Capanema.

Menos de dez anos depois, com a LDB de 1971, ocorreu uma grande redução no ensino de línguas estrangeiras, devido à obrigatoriedade de introduzir a habilitação profissional. Muitas escolas tiraram a língua estrangeira do currículo no primeiro grau, e no segundo grau, ofereciam não mais que uma hora por semana. Muitos alunos saíam do segundo grau sem ter tido visto uma língua estrangeira.

Em 1996, 25 anos depois da LDB anterior, a nova LDB (Lei $n^{\circ}$ 9.394) evidencia a necessidade do ensino de língua estrangeira nos ensinos fundamental e médio. No fundamental, a partir da quinta série, é obrigatoriamente incluído o ensino

\footnotetext{
${ }^{2} \mathrm{O}$ princípio fundamental do Método Direto é de que a segunda língua (L2) é aprendida por meio da L2. Assim, a língua materna nunca deve ser usada na sala de aula. Nas palavras de Leffa (1988, p. 216), "a transmissão do significado se dá através de gestos e gravuras, sem jamais recorrer à tradução. O aluno deve aprender a pensar na língua".
} 
de pelo menos uma língua estrangeira na parte diversificada, cuja escolha é determinada pela comunidade escolar; já no ensino médio, é incluída uma língua estrangeira como disciplina obrigatória, e uma segunda, em caráter optativo, de acordo com a disponibilidade da instituição.

Complementando a LDB de 1996, os PCNs (1998) surgem como diretrizes para orientar os professores com relação ao ensino de línguas no contexto educacional brasileiro. A seguir, na próxima seção, descrevemos as principais características desse documento, e apresentamos a concepção de língua que o norteia, partindo das considerações sobre os principais momentos dos estudos da linguagem e das principais concepções de línguas predominantes na história da Linguística.

\section{OS PCNS PARA O ENSINO FUNDAMENTAL}

Os PCNs (1998) para o ensino fundamental são documentos oficiais, criados pelo Ministério da Educação (MEC), que têm por finalidade orientar o ensino de todas as disciplinas da matriz curricular das escolas brasileiras. Foram elaborados a partir da Lei de Diretrizes e Bases/LDB (1996), que normatiza a educação no Brasil, como uma tentativa de legitimar o que nela estava escrito. Baseados no Princípio da Transversalidade, os PCNs destacam o contexto maior em que a língua estrangeira deve ser inserida. Esse documento não propõe uma metodologia específica para o ensino de línguas, mas orienta para uma abordagem Sociointeracional, com foco no desenvolvimento da leitura, justificada pelas condições de aprendizagem possibilitadas pelas instituições públicas brasileiras (como a reduzida carga horária, pouco domínio das quatro habilidades pelos professores, escassez de materiais didáticos, etc.) que inviabilizariam $\mathrm{o}$ desenvolvimento das quatro habilidades comunicativas (ouvir, falar, ler e escrever). 


\section{Atos de Pesquisa em Educação - ISSN 1809-0354 \\ Blumenau, v. 13, n.1, p.152-168, jan./abr. 2018 \\ DOI: http://dx.doi.org/10.7867/1809-0354.2018v13n1p152-168}

De acordo com a introdução aos PCNs (BRASIL, 1998, p. 63) para o terceiro e quarto ciclos do ensino fundamental $-5^{\mathrm{a}}$ a $8^{\mathrm{a}}$ séries $^{3}$, a aprendizagem de língua estrangeira é:

[...] uma possibilidade de aumentar a percepção do aluno como ser humano e como cidadão. Por isso, ela vai centrar-se no engajamento discursivo do aluno, ou seja, em sua capacidade de se engajar e engajar outros no discurso, de modo a poder agir no mundo social. Para que isso seja possível é fundamental que o ensino de Língua Estrangeira seja balizado pela função social desse conhecimento na sociedade brasileira. Tal função está relacionada, principalmente, ao uso que se faz da Língua Estrangeira via leitura, embora se possam também considerar outras habilidades comunicativas, em função da especificidade de algumas línguas estrangeiras e das condições existentes no contexto escolar. Os conteúdos de Língua Estrangeira se articulam com os temas transversais, pela possibilidade que a aprendizagem de línguas traz para a compreensão das várias maneiras de se viver a experiência humana. Além disso, ainda que seja desejável uma política de pluralismo linguístico, é preciso considerar aspectos da história dos alunos, da comunidade e da cultura local como critérios para orientar a inclusão de uma determinada língua estrangeira no currículo (BRASIL, 1998, p. 63).

A apresentação do documento também destaca que os temas centrais dos PCNs de língua estrangeira são: cidadania, consciência crítica e aspectos sociopolíticos da aprendizagem de língua estrangeira, os quais, de acordo com a proposta, articulam-se com os temas transversais, possibilitando que a aprendizagem de línguas se configure como "espaço para se compreender, na escola, as várias maneiras de se viver a experiência humana" (BRASIL, 1998, p. 15). Conforme o documento, ao longo dos quatro anos do ensino fundamental, espera-se com o ensino de LE que o aluno seja capaz de:

- identificar no universo que o cerca as línguas estrangeiras que cooperam
nos sistemas de comunicação, percebendo-se como parte integrante de um
mundo plurilíngue e compreendendo o papel hegemônico que algumas
línguas desempenham em determinado momento histórico;
- vivenciar uma experiência de comunicação humana, pelo uso de uma
língua estrangeira, no que se refere a novas maneiras de se expressar e de
ver o mundo, refletindo sobre os costumes ou maneiras de agir e interagir e
as visões de seu próprio mundo, possibilitando maior entendimento de um
mundo plural e de seu próprio papel como cidadão de seu país e do mundo;

${ }^{3}$ Os PCNs (BRASIL, 1998) foram escritos antes da aprovação da Lei 11. 274, em fevereiro de 2006, que altera a duração do ensino fundamental de oito para nove anos. 


\section{Atos de Pesquisa em Educação - ISSN 1809-0354 \\ Blumenau, v. 13, n.1, p.152-168, jan./abr. 2018 \\ DOI: http://dx.doi.org/10.7867/1809-0354.2018v13n1p152-168}

- reconhecer que o aprendizado de uma ou mais línguas the possibilita o acesso a bens culturais da humanidade construídos em outras partes do mundo;

- construir conhecimento sistêmico, sobre a organização textual e sobre como e quando utilizar a linguagem nas situações de comunicação, tendo como base os conhecimentos da língua materna;

- construir consciência linguística e consciência crítica dos usos que se fazem da língua estrangeira que está aprendendo;

- ler e valorizar a leitura como fonte de informação e prazer, utilizando-a como meio de acesso ao mundo do trabalho e dos estudos avançados;

- utilizar outras habilidades comunicativas de modo a poder atuar em situações diversas (BRASIL, 1998, p. 66-67).

Partindo dos objetivos apresentados, observamos que há uma ênfase dada aos aspectos culturais que estão atrelados ao ensino de línguas, bem como nas relações e interações sociais entre os indivíduos. Nessa mesma perspectiva, no texto de apresentação, os PCNs apresentam as duas questões teóricas que ancoram o documento: a primeira é uma visão Sociointeracional ${ }^{4}$ da linguagem; e a segunda é uma visão Sociointeracional da aprendizagem, que já apontam para a concepção de língua que apresenta o documento.

Por enfoque Sociointeracional da linguagem, os PCNs entendem que:

[...] ao se engajarem no discurso, as pessoas consideram aqueles a quem se dirigem ou quem se dirigiu a elas na construção social do significado. É determinante nesse processo o posicionamento das pessoas na instituição, na cultura e na história. Para que essa natureza Sociointeracional seja possível, o aprendiz utiliza conhecimentos sistêmicos, de mundo e sobre a organização textual, além de ter de aprender como usá-los na construção social do significado via Língua Estrangeira. A consciência desses conhecimentos e a de seus usos são essenciais na aprendizagem, posto que focaliza aspectos metacognitivos e desenvolve a consciência crítica do aprendiz no que se refere a como a linguagem é usada no mundo social, como reflexo de crenças, valores e projetos políticos (BRASIL, 1998, p. 15).

E a visão Sociointeracional da aprendizagem pode ser compreendida como:

[...] uma forma de se estar no mundo com alguém e é, igualmente, situada na instituição, na cultura e na história. Assim, os processos cognitivos têm uma natureza social, sendo gerados por meio da interação entre um aluno e um parceiro mais competente.

Em sala de aula, esta interação tem, em geral, caráter assimétrico, o que coloca dificuldades específicas para a construção do conhecimento. Daí a

\footnotetext{
${ }^{4}$ A nomenclatura Sociointeracional empregada pelos PCNs (BRASIL, 1998) também é referida na literatura como Sociocultural, Sociointeracionista ou Histórico-Social.
} 


\section{Atos de Pesquisa em Educação - ISSN 1809-0354 \\ Blumenau, v. 13, n.1, p.152-168, jan./abr. 2018 \\ DOI: http://dx.doi.org/10.7867/1809-0354.2018v13n1p152-168}

importância de o professor aprender a compartilhar seu poder e dar voz ao aluno de modo que este possa se constituir como sujeito do discurso e, portanto, da aprendizagem (BRASIL, 1998, p. 15).

Sobre o que o documento entende por visão Sociointeracional, na seção Concepções teóricas do processo de ensino e aprendizagem de língua estrangeira, os PCNs destacam quais são as três percepções modernas da aprendizagem de LE: a Behaviorista, a Cognitivista e a Sociointeracional. Na sequência, o documento faz uma breve alusão às três visões, das quais destacamos a Sociointeracional que, de acordo com os PCNs, é considerada por muitos autores a mais adequada para explicar como as pessoas aprendem, e na qual essas orientações curriculares se baseiam.

Nessa visão, o foco é a interação entre o professor-aluno e aluno-aluno. De acordo com essa perspectiva:

[...] aprender é uma forma de estar no mundo social com alguém, em um contexto histórico, cultural e institucional. Assim, os processos cognitivos são gerados por meio da interação entre um aluno e um participante de uma prática social, que é um parceiro mais competente, para resolver tarefas de construção de significado/conhecimento com as quais esses participantes se deparem. O participante mais competente pode ser entendido como um parceiro adulto em relação a uma criança ou um professor em relação a um aluno ou um aluno em relação a um colega da turma. Na aprendizagem de Língua Estrangeira, os enunciados do parceiro mais competente ajudam a construção do significado, e, portanto, auxiliam a própria aprendizagem do uso da língua (BRASIL, 1998, p. 57).

Partindo desse excerto, podemos observar que, para o documento, a aprendizagem é concebida como forma de coparticipação social e como construção de conhecimento compartilhado. $O$ processo de aprendizagem é mediado principalmente pela linguagem e por meios simbólicos, sendo construído por um conhecimento conjunto entre o aluno e o professor e um colega.

Com relação à concepção de linguagem dos $\mathrm{PCNs}$, encontramos claramente, na seção intitulada Caracterização do objeto de ensino língua estrangeira, a natureza sociointeracional da linguagem. De acordo com esse documento, aprender línguas significa conhecer e usar a língua. Desse modo, para que uma LE seja ensinada, é necessário que se tenha uma "compreensão teórica do que é linguagem, tanto no que se refere aos conhecimentos necessários para usá-la 


\section{Atos de Pesquisa em Educação - ISSN 1809-0354 \\ Blumenau, v. 13, n.1, p.152-168, jan./abr. 2018 \\ DOI: http://dx.doi.org/10.7867/1809-0354.2018v13n1p152-168}

quanto ao uso que se fazem desses conhecimentos para construir significados no mundo social" (BRASIL, 1998, p. 27.

Para os PCNs, o uso da linguagem, verbal ou visual, é determinado pela sua natureza sociointeracional:

[...] pois quem a usa considera aquele a quem se dirige ou quem produziu um enunciado. Todo significado é dialógico, isto é, é construído pelos participantes do discurso. Além disso, todo encontro interacional é crucialmente marcado pelo mundo social que o envolve: pela instituição, pela cultura e pela história. Isso quer dizer que os eventos interacionais não ocorrem em um vácuo social. Ao contrário, ao se envolverem em uma interação tanto escrita quanto oral, as pessoas o fazem para agirem no mundo social em um determinado momento e espaço, em relação a quem se dirigem ou a quem se dirigiu a elas. É nesse sentido que a construção do significado é social. As marcas que definem as identidades sociais (como pobres, ricos, mulheres, homens, negros, brancos, homossexuais, heterossexuais, idosos, jovens, portadores de necessidades especiais, falantes de variedades estigmatizadas ou não, falantes de línguas de prestígio social ou não etc.) são intrínsecas na determinação de como as pessoas podem agir no discurso ou como os outros podem agir em relação a elas nas várias interações orais e escritas das quais participam. Vale dizer que o exercício do poder no discurso e o de resistência a ele são típicos dos encontros interacionais que se vivem no dia-a-dia. Quem usa a linguagem com alguém, o faz de algum lugar determinado social e historicamente.

Assim, os significados construídos no mundo social refletem os embates discursivos dos quais se participa com base nas posições ocupadas em certos momentos da história e em espaços culturais e institucionais específicos. Em outras palavras, os projetos políticos, as crenças e os valores dos participantes do discurso são intrínsecos aos processos de uso da linguagem (BRASIL, 1998, p. 28).

Sobre a relação entre a língua estrangeira e a língua materna, o documento aponta que o processo sociointeracional de aprender uma língua já foi realizado pelo aluno com a língua materna, fora da escola. O aluno já conhece a linguagem e sabe usá-la em sua língua materna. O papel da escola, então, é possibilitar que o aluno acesse usos da linguagem com os quais ele não está familiarizado em casa. Desse modo, o que a língua estrangeira pode fazer é aumentar o conhecimento sobre a linguagem que o aluno construiu sobre sua língua materna, por meio de comparações com a língua estrangeira em variados níveis; e possibilitar que o aluno se envolva nos processos de construção de significado na língua estrangeira, constituindo-se em um ser discursivo no uso da língua estrangeira. 


\section{Atos de Pesquisa em Educação - ISSN 1809-0354 \\ Blumenau, v. 13, n.1, p.152-168, jan./abr. 2018 \\ DOI: http://dx.doi.org/10.7867/1809-0354.2018v13n1p152-168}

Partindo da análise dos PCNs de língua estrangeira, observamos que a concepção de língua apresentada por eles está relacionada com a terceira concepção de língua, apontada por Koch (2006) e Travaglia (2009), que a concebe como um processo de interação, no qual a linguagem é o lugar da interação humana, lugar em que se constituem as relações sociais. Essa concepção está de acordo como o que Guimarães (2001) sugere para uma cena contemporânea nos estudos da linguagem, no século $X X I$, com as posições que indicam o estudo do linguístico como relacionado ao que está fora da língua, como os fatores sociais e culturais, os quais nos PCNs ocupam um papel de destaque na aprendizagem de LE.

A leitura do documento também evidencia as filiações teóricas e autores nos quais se embasam. Assim, os PCNs apresentam por base as Teorias Sociointeracionistas da linguagem, cujo principal teórico é Vygotsky, seguido por Bakthin. O documento aponta em vários momentos para pressupostos vygostskyanos, como a mediação simbólica, a zona de desenvolvimento proximal, o fator social como constituinte do indivíduo; e para pressupostos bakthinianos, como a interação com o texto, a relação do eu e o outro. Esses autores são citados na bibliografia do documento, que referencia Vygotsky (1994) e Bakhtin (1981), apesar de não citá-los literalmente no seu interior. Na sequência, tecemos as considerações finais deste trabalho.

\section{CONSIDERAÇÕES FINAIS}

Este trabalho objetivou explicitar a concepção de língua dos PCNs (BRASIL, 1998) para o ensino de língua estrangeira no ensino fundamental. Como resposta, observamos que a concepção que permeia o documento é a de que a linguagem é o lugar da interação humana, sendo compreendida como ação individual orientada para uma finalidade específica, na qual um indivíduo realiza práticas sociais pelo seu uso, dentro dos diferentes grupos de uma sociedade, nos distintos momentos da história. 
Pela linguagem, ideias, pensamentos e intenções são expressos, e os indivíduos estabelecem relações com outras pessoas. Por meio dela, o outro, participante ativo do discurso, é influenciado e influencia o falante. Os participantes se alteram e alteram seus papéis, suas representações de realidade, de sociedade e suas ações.

Com relação ao horizonte de retrospecção e projeção do ensino de LE no Brasil, a história evidencia que o país sempre sofreu influências de tendências de outros países, bem como de forças políticas internas, o que está refletido na produção dos documentos oficiais que norteiam e nortearam o ensino, em diferentes momentos históricos. No que concerne ao horizonte de projeção, assim como ocorreu na reforma do ensino médio, a Base Nacional Comum Curricular (BNCC) foi homologada pelo Ministério da Educação, em dezembro de 2017; e será implantada nos currículos das redes públicas e privadas, urbanas e rurais, em 2019. Dentre as principais mudanças nos currículos, a BNCC traz o desenvolvimento integral do aluno. As dez competências gerais norteadoras contemplam aspectos cognitivos, sociais e pessoais a serem desenvolvidos pelos estudantes, como pensamento científico, crítico e criativo, capacidade de argumentação, autonomia e resiliência; além de defender a aprendizagem ativa e a valorização do campo de experiência das crianças e jovens. No entanto, para o ensino de LE as novas diretrizes continuam apontando para a interação como aspecto essencial no processo de aprendizagem escolar como já era evidenciado, em 1998, quando os PCNs para o ensino fundamental foram publicados.

\section{EMANUELE COIMBRA PADILHA}

Doutoranda em Estudos Linguísticos pela Universidade Federal de Santa Maria (UFSM).

\section{REFERÊNCIAS}

BRASIL. Ministério da Educação e do Desporto. Secretaria de Ensino Fundamental. Parâmetros Curriculares Nacionais: terceiro e quarto ciclos do ensino fundamental: língua estrangeira. Brasilía. DF: MEC/SEF, 1998. 


\section{Atos de Pesquisa em Educação - ISSN 1809-0354 \\ Blumenau, v. 13, n.1, p.152-168, jan./abr. 2018 \\ DOI: http://dx.doi.org/10.7867/1809-0354.2018v13n1p152-168}

BRASIL. Ministério da Educação e do Desporto. Conselho Nacional de Educação. Conselho Nacional de Secretários de Educação. União Nacional dos Dirigentes Municipais de Educação. Base Nacional Comum Curricular. DF:

MEC/CNE/Undime/Consed, 2017.

GUIMARÃES, E. Os estudos sobre linguagens: uma história das ideias. Linguagem: cultura e transformação. Ago. de 2001. Disponível em:

http://www.comciencia.br/reportagens/linguagem/ling14.htm Acesso em: 06 abr.

2016.

GUIMARÃES, E. História da semântica: Sujeito, sentido e gramática no Brasil. Campinas, SP: Pontes, 2004.

GUIMARÃES, E. Linguagem e Conhecimento: Produção e Circulação da Ciência. In. Revista Rua. Campinas. n. 15, V2. p.5-14.Nov. de 2009.

KOCH, I. Desvendando os segredos do texto. 5. ed. São Paulo: Cortez, 2006.

LEFFA, V. J. Metodologia do ensino de línguas. In: BOHN, H. I.; VANDRESEN, P. Tópicos em lingüística aplicada: $O$ ensino de línguas estrangeiras. Florianópolis: Ed. da UFSC, 1988. p. 211-236.

LEFFA, Vilson J. O ensino de línguas estrangeiras no contexto nacional. Contexturas, APLIESP, n. 4, p. 13-24, 1999.

MULIK, B. K. O ensino de língua estrangeira no contexto brasileiro: um passeio pela história. Disponível em:

https://www.academia.edu/1506870/O_ENSINO_DE_L\%C3\%8DNGUA_ESTRANGE IRA_NO_CONTEXTO_BRASILEIRO_UM_PASSEIO_PELA_HIST\%C3\%93RIA Acesso em: 22 abr. 2016.

ORLANDI, E. P. Língua e conhecimento lingüístico. São Paulo: Cortez, 2002.

PAIVA, V.L.M.O. A LDB e a legislação vigente sobre o ensino e a formação de professor de língua inglesa. In: STEVENS, C.M.T e CUNHA, M.J. Caminhos e Colheitas: ensino e pesquisa na área de inglês no Brasil. Brasília: UnB, 2003. p.5384

SCHERER, A.E.; MARTINS, S. T; SCHNEIDERS, C.M. Saussure e os estudos saussurianos no sul: algumas reflexões. In: Língua e Instrumentos Linguísticos, v.1, p. 73-94, 2015.

TRAVAGLIA, I. C. Gramática e interação: uma proposta para o ensino de gramática. São Paulo: Cortez, 2009. 